\title{
Discourse on Indonesian Piano Composition for Music Education
}

\author{
Hendrik Leonard Simanjuntak \\ Pengkajian Seni Pertunjukan dan Seni Rupa \\ Sekolah Pascasarjana Universitas Gadjah Mada \\ Universitas HKBP Nommensen \\ Medan, Indonesia \\ hendriksimanjuntak1979@gmail.com
}

\author{
Lono Lastoro Simatupang \\ Pengkajian Seni Pertunjukan dan Seni Rupa \\ Sekolah Pascasarjana Universitas Gadjah Mada \\ Yogyakarta, Indonesia \\ Lono_simatupang@yahoo.com
}

\author{
Viktor Ganap \\ Pengkajian Seni Pertunjukan dan Seni Rupa \\ Sekolah Pascasarjana Universitas Gadjah Mada \\ Yogyakarta, Indonesia \\ Viktor.ganap@yahoo.com
}

\begin{abstract}
Indonesia is an archipelago consisting of various tribes, cultures, and rich in diverse musical traditions, spreading from Sabang to Merauke. This archipelago music wealth must be maintained and developed continuously through various creativity and education as part of building national identity. The creativity of Indonesian composers in composing piano compositions is realized through the concept of 'new' composition which reflects things related to 'keindonesiaan'. Their composition works later became a discourse to become an integral part of Indonesian piano music education. The archipelago idiom material works can be the basis for repositioning the music education system, especially in music analysis which includes; texture, form, scale, sound color; and music practice. This paper uses two approaches to discuss composition and education; (1) historical musicology, namely studies relating to history, notation, performance practices, and instrumentation; and (2) Rationalizing Indonesian piano music education, which is related to curriculum development.
\end{abstract}

Keywords - composition; piano; Indonesia; analysis

\section{INTRODUCTION}

The experience of the author as a piano music educator in various formal and non-formal institutions for more than 15 years is a long enough journey to experience, observe and discover the dynamics of piano music education in Indonesia. In terms of quantity, piano education in Indonesia has experienced rapid development and its presence has received a positive response from the communityWe easily find a variety of formal and non-formal education that offers piano music, both for university level, school, and music courses. All levels of music piano education in Indonesia are still attached to the piano curriculum in the west, which are standardized based on their level. This condition has been going on for a long time, starting from the era of Dutch colonialism to the postindependence of Indonesia. There is no effort from various parties to develop a piano curriculum that accommodates indigenous Indonesian culture.

The curriculum is about what must be learned. The curriculum is in a much broader domain, and can include activities that are built or determined socially, chosen in a certain way from the culture of the community [1]. In this context, Indonesian piano education can be said to run in the wrong direction because the piano curriculum is not socially determined and the material is not derived from the culture of Indonesian society. We talk about something that is not sourced from our own cultural domain, but something that is outside of our culture. How can we support western culture simply by discussing some piano composition works written by Bach, Mozart, Beethoven, Chopin, Brahms? This is the wrong way of thinking, because what? Studying a culture requires social interaction in a relatively long time. Even though we study and play some of their piano works, it is still at the level of the composer's ideas and ideas, not in the overall cultural understanding of the composer. Therefore, the curriculum used today is a legacy of the era of colonialism, and if we are honest, kurikulum tidak ada hubungannya langsung dengan budaya Indonesia. Even if we try to analyze the piano curriculum that runs now, we do not find out exactly how the selection of compositions is done; basic cultural material considerations incorporated into the curriculum how is the process, by whom, and what results are desired. Basil Bernstein [2] suggests that 'how a society chooses, classifies, distributes, transmits, and evaluates educational knowledge that is considered public reflects the principles of social control'.

The adoption of the curriculum that is happening now has implications for several things, namely; (1) isolated learning material in western culture and does not provide space for the realm of Indonesian culture; (2) western methodology 
approach that does not always conform to the habitus; and (3) students consisting of diverse cultural backgrounds require a different approach. These three aspects need to be considered and considered, whether piano music education in Indonesia already has the right place? Curriculum development can be one way to accommodate the entry of Indonesian cultural material into the piano curriculum. Thus, we have provided space for innovative means aimed at perfecting, expanding, or adding Indonesian piano education curriculum material.

The researcher realized that this was not easy to do, because of the long-standing doctrine in piano education in Indonesia. The influence of the curriculum that has been running so far has sometimes hampered the acceptance of new material in the piano education curriculum in Indonesia. This is a challenge for researchers to discourse the works of Indonesian piano composers as an integral part of the piano education curriculum in Indonesia. Reconceptualization of Indonesian piano music education curriculum is a necessity, that is, by providing space for the use of Indonesian piano composition works in the curriculum. There are four ways to reform the Indonesian piano education curriculum, namely: (1) a more comprehensive view of musical behavior; (2) various styles of Nusantara music; (3) a sense of integrated music as a realized experience; and (4) a deeper understanding of music [3].

\section{METHODS}

The research method used is a qualitative method. To see the 'keindonesian' representation in Indonesian piano composition, the researcher will only analyze Suita Kaliurang by Mochtar Embut. At least, the analysis of this work can stimulate us to the aesthetics of Indonesian piano works that are different from those in the West, so that it can be used as part of piano music learning in Indonesia. Researchers also observed some music education in Indonesia to see the extent to which the piano curriculum was applied and how they responded to the existence of Indonesian piano compositions. The analysis of Suita Kaliurang is done by a musicology approach. Approach to the Indonesian piano music education curriculum, researchers used Mehlinger's opinion that said that Every country employs a wide range of social institutions to induct new members into its society, transmit the cultural heritage to the young and to develop in its people a feeling of national pride. The major means for accomplishing these goals is through educational institutions... [and] within the schools, the major responsibility falls on the social studies programme [4].

Research on the discourse of Indonesian piano music composition for music education has never been done by Indonesian researchers before. This opinion is certainly supported by facts in the field, based on the results of the literature review conducted, the researchers did not find any previous studies that examined related to this topic. Through literature review, researchers found important data where there were three Indonesian researchers who wrote about the biography of Indonesian composers, that is; Trisutji Kamal, Amir Pasaribu and Ananda Sukarlan. This thesis research is supporting data to obtain information related to their existence and contribution in the development of art music in Indonesia.

Kismiyati in his thesis entitled "Komponis dan Pianis Wanita Indonesia Trisutji Kamal: Sebuah Demografi", discussing the journey of education to the role of Trisutji Kamal in the development of music in Indonesia, materialized in terms of; Performing works at national and international level activities and as pianists. Classification of Trisutji Kamal composition works is divided into two types, namely; (a) compositions for solo, ensemble, symphony, choir, opera; and (b) arrangements for vocals and instrumentals [5]. Nathalia in his thesis "Kajian Tekstual The Drupadi Trilogy Karya Ananda Sukarlan", discuss the relationship of composition works with habitus and interrelation of traditional Indonesian elements with Western music in them, and see the role of the work as an identity for the composer himself [6]. Sitorus [7] in his thesis "Biografi Amir Pasaribu dan PemikiranPemikirannya dalam Bidang Seni dan Budaya", about the position of Amir Pasaribu was a musician, composer, critical, thinker and player.

\section{RESULTS AND DISCUSSION}

The 20th century was a turning point in the history of Indonesian modern music where Indonesian piano composers practiced experimentally on archipelago music idioms. They took traditional music and folk music sourced from various regions in Indonesia to be made into musical material in building their piano composition works. Nusantara music that is varied and perfect in its form has expressive power in its initial context, then assimilated in such a way as to become an artistic piano work (listeners can still recognize the source of musical idioms assimilated in piano composition works compiled by Indonesian composers).

The treatment of Indonesian composers for various musical musical idioms of the archipelago is not merely 'imitation', then lends it or moves it in the piano works they write. According to the researcher, Indonesian piano composers had previously studied the characters of these Nusantara music idioms well as part of their own mother tongue. They also involved and experienced various musical activities in a real way through art education in schools and musical performances. After all the processes have been carried out, they have just arrived at the stage of creativity in composition, what they experience and learn (about Indonesian music) during the process in the cultural realm will have implications for their originality of work.

Suita Kaliurang consists of three parts with different characters and uses keys that are not similar. Embut relaxes the composition of Suita Kaliurang by not following the principles of Suite Bach A-C-S-O-G, and with the composer afterwards. Embut uses more metaphors to associate his musical work with things that are more directed towards 'keindonesiaan' (pointing to the characteristics of a particular area). Suita Kaliurang is arranged with the principle of three movements, namely; Getuk Lindri (moderato); Rumah Gadang (allegro ma non tanto); and Merapi (andante). 
Embut Mohtar replaced the principle of A-C-S-O-G in Bach's suita in the work of Suita Kaliurang, which actually has a meaning that is close to 'taste' in Indonesia. Getuk Lindri is one type of traditional snacks where the basic ingredients are steamed or boiled cassava, originating from Central Java [8]. Rumah Gadang is a traditional Minangkabau traditional house, West Sumatra Province. Rumah Gadang is also called by another name by the local community with the name Rumah Bagonjong or Rumah Baanjuang [9]. Merapi adalah istilah lain untuk menyebut gunung berapi. Merapi is one of the most active volcanoes in Indonesia, located in the middle of the island of Java. The south side slope is in the administration of Sleman Regency, Special Region of Yogyakarta, and the rest are in the Central Java Province, namely Magelang Regency on the west side, Boyolali Regency on the north and east side, and Klaten Regency on the southeast side [10].

The discourse of the composition of Suita Kaliurang composition is the strength of national musical idioms that represent Javanese musical idioms. The treatment of melodies in idioms allows Indonesian composers to loosen sound colors, melody and harmony with a wider range. The attachment of idioms to triads is not limited in terms of harmony in the Western musical tradition because the idiom melody used can be constructed from every note it has. This gives space for composers to put melodies beyond the general understanding of major and minor scales.

The first movement of Suita Kaliurang Getuk Lindri, starting with monophonic texture, where the same melody is played simultaneously in octave intervals, but for bar 5 and so on it uses homophonic melodic textures.

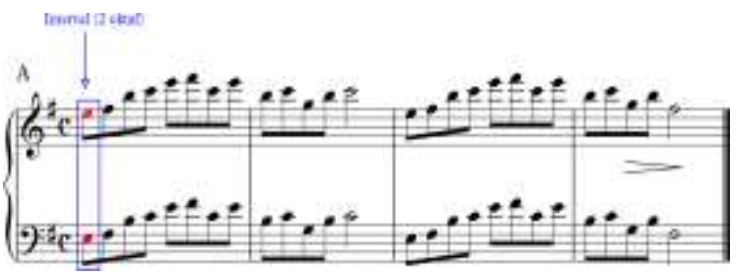

Fig. 1. Monophonic Texture - Getuk Lindri

Mochtar Embut relaxed the use of the form of suita composition by avoiding the principle of binary forms as commonly found during the Baroque period. Mochtar Embut prefers to use the ternary form. The key approach (tonality) used by composers in part A gives us an alternative to two perspectives in music, namely; $\mathrm{G}$ major or $\mathrm{E}$ minor. This is a gimmick that is intentionally done to obscure the system of tonality and show the richness of archipelago idioms where the melody of idioms cannot be absolutely determined by the Western musical approach, because the arrangement of melodies makes it possible to enter major and minor categories simultaneously or separately depending on the concept of cultivation of the composer.

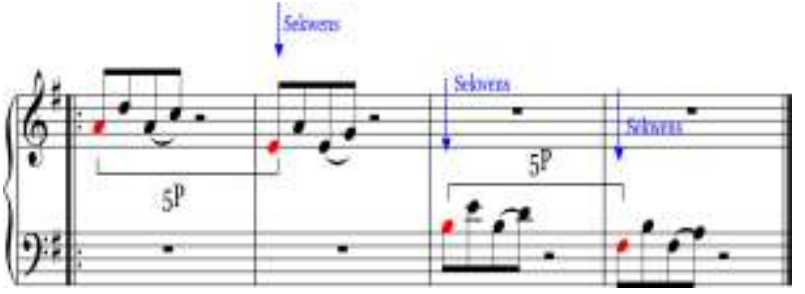

Fig. 2. Pattern of Getuk Lindri sequence

The composer seems to be back to using the "obscure" pattern of the dominant level in part B as is usually the case for baroque suite. Bar 17-20 is the last part of the first Suita Kaliurang movement with a polyphonic texture, and harmony IV-V-IV-V. There is a repetition of the rhythm and melody from bar 5 and bar 7 with changes to the tone being held, and the position of bass sounds that are played constantly in two beats to reinforce harmony.

The second movement of the Suita Kaliurang - Rumah Gadang is arranged in monophonic texture with melodic voicing on the bass key (left hand), while the accompaniment is in the treble key (right hand). Bar 2-5, it is clear how composers emphasize the tone and octave interval in the first and third beats with a pattern that tends to rise. Anticipation of boredom rhythms and melodies in bars 2-5 is then solved with a downward pattern in bar 6-9. Bar 10-13 are repetitions of rhythmic patterns and melodies from bars 2-5 with slight changes.

Bar 14-21, the composer gives a different melodic pattern from part A. Ornamentation adds to the beauty of the melody supported by harmonic progressions which move down in intervals of $2 \mathrm{M} / 2 \mathrm{~m}$. Bar 22-29 is a new variation part of bars 14-21.

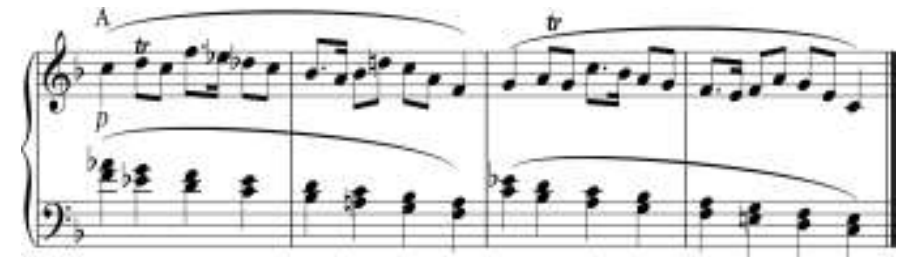

Fig. 3. Use of ornamentation

The third movement of Suita Kaliurang - Merapi is arranged with a strong rhythmic pattern that is voiced in the bass key (left hand). Melody is a repetition pattern within the same nuances of Javanese music. The composition of Merapi is arranged symmetrically (every eight bars), which is divided into two phrases. The concept of cultivating Merapi bears a resemblance to Getuk Lindri in terms of initial voicing which starts with an octave melody. The three movements of Suita Kaliurang begin with monophonic textures as a consequence of ensemble music play (there is a solo section and there is time to play as a whole.) 


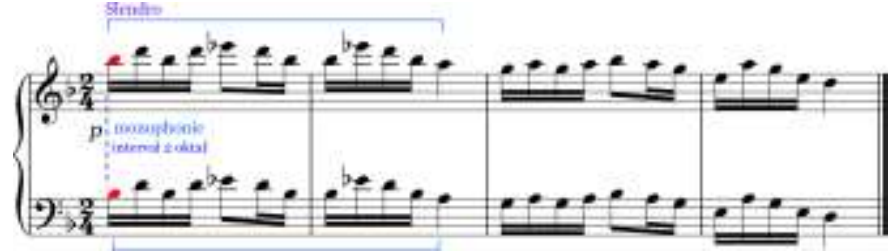

Fig. 4. Monophonic texture and slendro scale

Bar 9-16 is the development of variations on bass keys (left hand), where the rhythmic pattern of the melody remains the same as bar 1-8. This reminds us again of the classic composition concept that prioritizes variations in variety to release boredom in composition. Mochtar Embut uses an accompaniment pattern that is similar to the classic ragtime accompaniment pattern, where the left hand material consists of note and chords.

Bar 17-24 is a continuation of bar 9-16 with an emphasis on accompaniment variations by reducing the value of the second beat note, while the melody is developed by sequens. Bars 25-32 are part $\mathrm{B}$, which is new material where the melody is arranged by octave $(5 \mathrm{P}+4 \mathrm{P})$, while the accompaniment pattern on the bass key is more of a rhythm variation by the first tap and second beat.

Bars 33-40 are material repetitions from 25-32 bars arranged down in 5P intervals. This section is a preparation for going to section $A^{\prime}$ which is characterized by monophonic textures in bar 40. Bar 41-48 is part A with fragmentation of previous accompaniment variations. Bar 49-52 is an additional part / cover (coda) arranged in monophonic texture while maintaining the melody repetition and rhythm of part A.

\section{CONCLUSION}

Indonesian piano education must provide space for the use of Indonesian composers' work in the curriculum. This is one way to teach the wealth of Indonesian music through piano education. Basically we do not reject or anti against the western piano curriculum that has been going on so far, but we need to place Indonesian work in a well-organized piano curriculum based on levels.

Wiles and Bondi [11] stated that the curriculum is a "process in which the choice of designing learning experiences for students is made and then activated through a series of coordinated activities". In this context, we offer three initial approaches to placing Indonesian piano composition works in the music education curriculum, namely; (1) piano composition works currently documented and then analyzed based on the level of difficulty based on grade. Then, we can directly place Indonesian composition works in the ongoing curriculum; (2) reducing Indonesian piano composition works which have a virtuoso level to be the teaching material for the basic level. The aim of reducing Indonesian piano composition works is for beginner students to learn from an early age; and (3) music analysis learning materials containing Indonesian piano composition works (especially for college students.)

\section{REFERENCES}

[1] Ross, Alistair, Curriculum: Construction and Critique, Fetter Lane, London: Falmer Press, 2000

[2] Bernstein, Basil, 'On the Classification and Framing of Educational Knowledge', in Young, M.F.D. (ed.) Knowledge and Control: New Directions for the Sociology of Education, London: Collier-Macmillan, 1971a.

[3] Barrett, Janet R, "Currents of Change in the Music Curriculum" In International Handbook of Research in Arts Education (ed.) Liora Bresler, Springer, 2007, pp. 147-178.

[4] Mehlinger, H. (ed.) 'Social Studies Around the World', in UNESCO Handbook for the Teaching of Social Studies, Beckenham: Croom Helm, 1981.

[5] Christian Kismiyati, "Komponis dan Pianis Wanita Indonesia Trisutji Kamal: Sebuah Demografi” Tesis Untuk Mencapai Derajat Sarjana S2 pada Program Pengkajian Seni Pertunjukan dan Seni Rupa, Universitas Gajah Madja, Yogyakarta, 2008.

[6] Nirai Nathalia, "Kajian Tekstual "The Drupadi Trilogy Karya Ananda Sukarlan". Universitas Gajah Madja-Yogyakarta. Tesis untuk mencapa derajat Sarjana S2 pada Program Pengkajian Seni Pertunjukan dan Seni Rupa, Universitas Gajah Madja, Yogyakarta, 2014

[7] Eritha Rohana Sitourus, "Biografi Amir Pasaribu dan pemikiranpemikirannya dalam bidang seni budaya". Tesis Untuk Mencapai Derajat Sarjana S2 pada Program Pengkajian Seni Pertunjukan dan Seni Rupa, Universitas Gajah Madja, Yogyakarta, 2004.

[8] Retrieved from https://id.wikipedia.org/wiki/Getuk

[9] Retrieved from https://id.wikipedia.org/wiki/Rumah_Gadang

[10] Retrieved https://id.wikipedia.org/wiki/Gunung_Merapi

from

[11] Wiles, J. \& Bondi, J, Curriculum Development: A Guide to Practice. Upper Saddle River, NJ: Pearson Prentice Hall, 2007. 